\title{
Nutrient Retention and Haematological Indices of Broiler Starters Fed Lablab Seed Meal as the Source of Protein
}

\author{
Y. A. Bashar ${ }^{1}$, H.M. Tukur ${ }^{1}$, A.A. Sekoni ${ }^{2}$, and W. A. Hassan ${ }^{1}$ \\ ${ }^{1}$ Department of Animal Science, Usmanu Danfodiyo University, Sokoto \\ ${ }^{2}$ National Animal Production Research Institute, Shika, Ahmadu Bello University, Zaria
}

\begin{abstract}
Studies were carried out to determine the effect of feeding diets containing lablab seed meal (LSM) to replace groundnut cake (GNC) or full fat soya (FFS) as the major source of protein on nutrient retention and haematological parameters of broilers at the starter phase. Apparent crude protein, crude fibre and ether extract retentions $(\%)$ were highest $(\mathrm{P}<0.05)$ for broiler starters fed the LSM diet, while the retention of ash was similar $(\mathrm{P}>0.05)$ between those fed LSM and FFS diets, but significantly lower $(\mathrm{P}<0.05)$ for those fed the GNC diet. The retentions $(\%)$ of nitrogen free extract, calcium and phosphorus were highest $(\mathrm{P}<0.05)$ for starters fed LSM, while those fed FFS had values that were similar (P>0.05) to birds fed LSM or GNC. Most of the haematological parameters measured were similar amongst the treatments, except that packed cell volume (PCV) $(\%)$ and mean corpuscular volume $(\mathrm{MCV})(\mathrm{fl})$ were significantly lower $(\mathrm{P}<0.05)$ for broiler starters fed the GNC diet, while mean corpuscular haemoglobin concentration (MCHC) (\%) and Neutrophiles $(\%)$ were lowest $(\mathrm{P}<0.05)$ for those fed the LSM diet. All values were however within the normal ranges for healthy broiler starters. The results indicated that LSM can replace GNC and FFS in the diets of broilers at the starter phase, without compromising performance.

Key words: broiler starters, nutrient retention, haematological parameters, lablab seed meal.
\end{abstract}

\section{INTRODUCTION}

The biggest constraint to poultry production in Nigeria is cost of feed, which accounts for about 60 to $80 \%$ of the recurrent expenditure in intensive poultry production (Oluyemi and Roberts, 2000). This is because feedstuffs used in formulating and compounding diets for poultry are also in high demand for human consumption and industrial uses (Anike and Okeke, 2003) thus, alternative feeding stuffs must be sourced.

Protein for poultry is usually supplied from two major sources, i.e. animal and plant sources. Plant proteins are cheaper and therefore their use in large quantity ensures less expenditure as compared to animal proteins. However, the use of some of the plant protein sources is limited by their content of anti-nutritional factors. Such anti-nutritional factors include trypsin, chymotrypsin and amylase inhibitors, aflatoxins and polyphenolic compounds which tend to inhibit and obstruct the activity of digestive enzymes, thereby causing digestive losses (Singh, 1988).

Lablab purpureus (L) Sweet, also known as Dolichos lablab, Egyptian bean, Lablab bean,
Bonavist or Hyacinth bean (Hendricksen and Minson, 1985) and "Danwari" in Hausa language, is well grown by farmers in Sokoto and its environs. As a result of its high grain yield of up to $3 \mathrm{t} / \mathrm{ha}$, which compares favourably with the yield of soya beans ( 2 to $7 \mathrm{t} / \mathrm{ha}$ ) (Wood, 1983), a lot of seeds are produced and harvested. Unlike groundnuts and soya beans, lablab seed has not been widely used in poultry diet formulations despite the fact that it is cheaper than the two protein sources in the Sub-Saharan zone of Nigeria. Sarwatt et al. (1991) fed broilers with lablab seed meal (LSM) and obtained favourable results in terms of weight gain, feed intake, feed cdonversion ratio and dressing percentage. Similarly, Ogundipe et al. (2003) reported favourable weight gains in pullets fed diets in which lablab seed meal constituted $50 \%$.

Various researchers have reported the significance of haematological indices in relation to the health status or nutritional state of animals. Eggum (1976) revealed that blood is vital to life and before any meaningful work can be done on the biology of birds, detailed haematolgical study is imperative. This is 
because any abnormal variation in haematology impairs the primary physiological functions of the body. Studies on haematological parameters give a good understanding of the nutritional status of the feed fed to poultry. It also provides useful information on the metabolic profile, which is used to assess the bird's state of health (Suchy, 2000).

Commonly used haematological parameters measured during blood studies include red blood cell count (RBC), haemoglobin concentration $(\mathrm{Hb})$, leucocytes counts (WBC), erythrocyte; absolute (i.e. mean corpuscular haemoglobin $(\mathrm{MCH}))$ and derived (i.e. mean corpuscular heamoglobin concentration (MCHC)) values. Dietary differences affect erythrocyte values among group of animals (Akpodiete and Ologhobo, 1998). This could be due to poor nutritional status, alongside sub clinical diseases. It has been shown that rats fed restricted diets had lower PCV values than those fed the same diets ad-libitum. Retention of energy intake was also shown to be associated with relative elevation of MCHC values (Simarak et al., 2004). Eggum (1976) reported that $\mathrm{Hb}$ concentration, PCV and MCHC, are very sensitive to the level of protein intake by poultry. However, the use of PCV and $\mathrm{Hb}$ for protein assessment may be limited by the deficiency of other nutrients. Haemoglobin concentration is useful in detecting anaemia in avian species in general (Akpodiete and Ologhobo, 1998).

There is a direct relationship between quality of feed ingested and the blood composition of broilers. Significantly higher values of red blood cells, $\mathrm{Hb}$ and PCV were recorded in broilers fed high protein diets than those fed low protein (Mirtuka and Rawnsley, 1997). Macrocytic condition of erythrocytes for mean cell haemoglobin $(\mathrm{MCH})$, mean cell haemoglobin concentration (MCHC) and mean corpurscular volume (MCV) were reported to be within the ranges of 33 to 47 (pg), 26 to 35 (g/dl) and 90 to 140 (fl), respectively. Simarak et al. (2004) reported the following values for Thailand domestic fowls: $2.19 \times 106 \mu$ for RBC, $2.05 \times$ $104 \mu \mathrm{l}$ for $\mathrm{WBC}, 8.5 \mathrm{~g} / \mathrm{dl} \mathrm{Hb}, 39.11 \mathrm{pg}$ for $\mathrm{MCH}$, $27.79 \mathrm{~g} / \mathrm{dl}$ for $\mathrm{MCHC}$ and 141.39fl for MCV, respectively. This work was therefore aimed at evaluating the effect of the inclusion of lablab seed meal in the diets of broilers at the starter phase on nutrient retention and haematological parameters.

\section{MATERIALS AND METHODS}

Description of Experimental Site: The experiment was conducted at the Sokoto State Veterinary Center, located at Aliyu Jodi road in Sokoto metropolis. Sokoto is located on latitude $13^{\circ} 4^{\prime} \mathrm{N}$ and longitude $5^{\circ} 13^{\prime} \mathrm{E}$ in Northwestern Nigeria (Fullard, 1973; Reuben, 1981). The state is situated in the savannah vegetation zone of Nigeria with a semi arid climate. It shares border with Niger Republic to the north, Zamfara State to the east and Kebbi State to the southwest. It occupies a land area of 26,648 square kilometers (Adamu, 1992).

Processing of Full Fat Soya and Lablab Seed Meal: Soya bean and lablab seeds were soaked in cold water for about 20 hours and later boiled for between 30 and 40 minutes according to the methods of Ogundipe et al. (2003). The boiled water was decanted and the boiled seeds were dried in open air for five days before they were ground into meal.

Experimental Procedure:Two hundred and thirty four day-old broilers of the anak strain were divided into nine groups of twenty-six chicks, each representing a replicate. Three replicates (i.e. 78 birds), consisting of a treatment, were randomly assigned to one of the following dietary treatments: diet 1,2 and 3 containing GNC, FFS and LSM, respectively with an average of $2950 \mathrm{kcal} / \mathrm{kg}$ metabolizable energy (ME) and $23.15 \%$ crude protein (CP) according to the recommendations of NRC (1977). The diets were fed to the birds for the first four weeks of age.

Apparent Nutrient Retention Trial: At the fourth week of age, three chicks from each replicate were transferred to clean metabolic cages and fed the corresponding treatment diets. Feed was offered at $90 \%$ of the average daily feed intake to ensure that it was all consumed and to minimize wastage (Oluyemi and Roberts, 2000). Feed and water were served early morning between 7.00am and $8.00 \mathrm{am}$. The trial lasted for six days. The first three days were considered as adaptation period and the last three days as experimental period. Records of feed intake and faeces voided were taken during 
the last three days. Feed and faecal samples were weighed and oven dried in the laboratory. The samples were later analyzed for proximate composition according to the methods of AOAC (1990). Calcium was analyzed by EDTA titration method. The Bray number 1 method was used to determine phosphorus, while sodium and potassium contents were determined by the Flame Photometric Method. Apparent nutrient retention was calculated using the formula below.

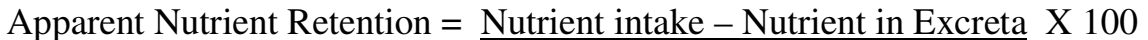

Haematological Analysis:At the end of the fourth week, three birds from each replicate were fasted over night. Blood samples were collected in Ethylene Diamine Tetra Acetic Acid (EDTA) treated bottles for determination of packed cell volume (PCV), red blood cell (RBC), white blood cell (WBC) and haemoglobin concentration $(\mathrm{Hb})$ at the Usmanu Danfodiyo University Veterinary Teaching Hospital. Mean cell haemoglobin concentration (MCHC), mean cell haemoglobin $(\mathrm{MCH})$ and mean corpuscular volume (MCV) were later calculated according to the methods of Jain (1986).

Statistical Analysis: Data generated during the study were subjected to analysis of variance in a Completely Randomized Design and means were separated by LSD using the general linear model programme of the SPSS computer package (SPSS, 1999).

\section{RESULTS AND DISCUSSION}

Apparent Nutrient Retention of the Birds at the Starter Phase: Apparent nutrient retention of experimental birds is presented in table 2. Dry matter retention varied between $71 \%$ for the FFS diet to $73 \%$ for the GNC diet. There was no significant $(\mathrm{P}>0.05)$ difference between the treatments. However, retention of $\mathrm{CP}, \mathrm{CF}$ and EE were better for the LSM diet compared to the GNC and FFS diets $(\mathrm{P}<0.05)$. Ash was retained $(\mathrm{P}<0.05)$ for the LSM $(71 \%)$ and GNC $(69.7 \%)$ diets compared to the FFS (60\%) diet. Even though $\mathrm{Ca}$ and $\mathrm{P}$ digestibilities were better for the LSM and FFS diets compared to the GNC diet, the differences were significant only between the LSM and GNC diets. Retention of $\mathrm{Mg}, \mathrm{Na}$ and $\mathrm{K}$ did not differ between the treatments. Generally, retention of mineral components (75 to 97\%) was higher than that of the other proximate components (48 to $76 \%$ ).
Nutrient intake

The superiority in the retention of crude protein by birds fed LSM might be due to low digestibility of GNC, which was earlier reported by Oluyemi and Roberts (2000). It could also be due to the fact that GNC was fed as a cake while the other two plant proteins were fed as full fat meals. The values obtained in the present study were however lower than the $80.72 \%$ crude protein retention reported by Kwari et al. (2004), when diets containing sorrel seed meal were fed to broilers. Crude fibre retention was lower than the retention of other nutrients. This could be due to the inability of poultry to efficiently digest non-starch polysaccharides (Oldale and Hoffman, 1996). Non-starch polysaccharides usually contain water insoluble fractions made of pentosans and $\beta$, D-glucans, whose glycosidic linkages are not hydrolysable by monogastric enzymes. They are however hydrolyzed by microbial enzymes. Since microbial fermentation is not pronounced in poultry, the utilization of fibre is not expected to be as efficient as that of other nutrients (Choct and Kocher, 2002).

Haematological Parameters of the Birds at the Starter Phase: Table 3 shows the influence of the experimental diets on the haematological parameters of broilers at 4 weeks of age. Packed cell volume $(\mathrm{PCV})$ was higher $(\mathrm{P}<0.05)$ for birds fed the FFS and LSM diets (25\%) compared to those fed the GNC containing diet (23\%). MCV was higher for birds on the LSM diet $(100 \mathrm{fl})$ compared to those on the GNC diet ( $84 \mathrm{fl})$. For $\mathrm{MCHC}$, the GNC diet had the highest value of $36 \%$, which was significantly different $(\mathrm{P}<0.05)$ from the LSM value of $31 \%$. Level of neutrophils was higher $(\mathrm{P}<0.05)$ for birds on the GNC (40\%) and FFS (42\%) diets compared to those on the LSM diet (36\%). All the other blood parameters did not differ significantly $(P>0.05)$ between the treatments. 
The low protein retention recorded for the GNC diet could have contributed to lower PCV observed for the diet, because retained proteins furnish the body with amino acids that are used for the synthesis of body proteins including blood proteins. Coles (1986) reported that PCV is the quickest indirect way of assessing values of red blood cells in circulation and is often used as a simple screening test for anaemia.

Table 1. Gross composition (\%) of experimental diets fed to broilers at the starter phase (0-4 weeks)

\begin{tabular}{llll}
\hline Ingredients (\%) & Diet 1(GNC) & Diet 2 (FFS) & Diet 3 (LSM) \\
\hline Maize & 55.55 & 43.50 & 28.00 \\
GNC & 31.00 & 0 & 0 \\
FFS & 0 & 33.00 & 0 \\
LSM & 0 & 0 & 55.35 \\
Rice bran & 4.00 & 11.00 & 0 \\
Blood meal & 4.00 & 4.50 & 8.00 \\
Limestone & 1.50 & 2.55 & 1.00 \\
Bone meal & 3.00 & 4.50 & 3.00 \\
Vit/mineral premix* & 0.25 & 0.25 & 0.25 \\
Salt & 0.30 & 0.30 & 0.30 \\
Methionine & 0.20 & 0.20 & 0.20 \\
Lysine & 0.20 & 0.20 & 0.20 \\
Vegetable oil & 0 & 0 & 3.70 \\
\hline Total & $\mathbf{1 0 0}$ & $\mathbf{1 0 0}$ & $\mathbf{1 0 0}$ \\
\hline Calculated chemical & & & \\
analysis & & 2959.64 & 2942.97 \\
ME (Kcal/kg) & 2954.39 & 23.13 & 23.15 \\
CP $(\%)$ & 23.18 & 4.11 & 3.13 \\
CF $(\%)$ & 3.20 & 9.13 & 5.85 \\
EE $(\%)$ & 4.65 & 0.58 & 0.35 \\
Methionine $(\%)$ & 0.49 & 1.50 & 1.08 \\
Lysine (\%) & 1.25 & 2.64 & 1.52 \\
Calcium $(\%)$ & 1.72 & 0.93 & 0.74 \\
Available phosphorus $(\%)$ & 0.59 & & \\
\hline
\end{tabular}

Table 2. Apparent nutrient retention (\%) of broilers fed at the starter phase (0-4 weeks of age)

\begin{tabular}{lllll}
\hline Parameters & Diet 1 (GNC) & Diet 2 (FFS) & Diet 3(LSM) & SEM \\
\hline Dry matter & 73.27 & 71.53 & 73.85 & 0.79 \\
Crude protein & $60.00^{\mathrm{b}}$ & $65.67^{\mathrm{b}}$ & $74.67^{\mathrm{a}}$ & 2.33 \\
Crude fibre & $48.00^{\mathrm{b}}$ & $49.00^{\mathrm{b}}$ & $60.67^{\mathrm{a}}$ & 1.64 \\
Ether extract & $70.00^{\mathrm{b}}$ & $62.67^{\mathrm{c}}$ & $75.67^{\mathrm{a}}$ & 1.59 \\
Ash & $69.67^{\mathrm{a}}$ & $60.00^{\mathrm{b}}$ & $71.00^{\mathrm{a}}$ & 1.50 \\
NFE & $64.33^{\mathrm{b}}$ & $69.77^{\mathrm{ab}}$ & $76.67^{\mathrm{a}}$ & 2.15 \\
Calcium & $75.00^{\mathrm{b}}$ & $81.00^{\mathrm{ab}}$ & $83.00^{\mathrm{a}}$ & 2.08 \\
Phosphorus & $85.67^{\mathrm{b}}$ & $91.33^{\mathrm{ab}}$ & $95.00^{\mathrm{a}}$ & 2.24 \\
Magnesium & 96.33 & 94.00 & 97.00 & 1.12 \\
Sodium & 95.33 & 95.33 & 97.00 & 0.92 \\
Potassium & 95.00 & 94.67 & 95.33 & 0.79 \\
\hline a,b: Means along the same row with different superscripts are significantly different (P<0.05)
\end{tabular}

The PCV values obtained for the three test diets were all within the normal range of 22 to $35 \%$ reported by Jain (1993). They were however lower than the values of 25 to $45 \%$ reported by Mirtuka and Rawnsley (1997). The higher PCV value obtained for the FFS diet is expected, 
since soya bean is known to an excellent amino acid profile which is comparable to fish meal, cow milk and human milk, although it is suboptimal in cystein and metionine (Liener, 1979; McDonald et al., 1988). Lablab seed meal is also reported to contain appreciable amounts of lysine, methionine, cystein and tryptophan (Nagabushanam et al., 1962; Lambourne and Wood, 1985).

Table 3: Haematological indices of birds fed diets containing GNC, FFS or LSM as the major plant protein source during the starter phase (0-4 weeks of age).

\begin{tabular}{|c|c|c|c|c|}
\hline Parameter & Diet 1 (GNC) & Diet 2 (FFS) & Diet 3 (LSM) & SEM \\
\hline PCV (\%) & $22.67^{b}$ & $25.33^{\mathrm{a}}$ & $25.33^{\mathrm{a}}$ & 0.75 \\
\hline $\mathrm{RBC}(\mathrm{x} 106 \mu \mathrm{l})$ & 2.78 & 2.52 & 2.42 & 0.11 \\
\hline WBC (x104 $\mu \mathrm{l})$ & 23.50 & 23.07 & 24.70 & 0.78 \\
\hline $\mathrm{Hb}(\mathrm{g} / 100 \mathrm{ml})$ & 8.23 & 8.40 & 7.80 & 0.37 \\
\hline sMCV (fl) & $83.91^{\mathrm{b}}$ & $100.84^{\mathrm{ab}}$ & $105.62^{\mathrm{a}}$ & 5.95 \\
\hline $\mathrm{MCH}(\%)$ & 30.39 & 33.48 & 32.56 & 2.31 \\
\hline $\mathrm{MCHC}(\%)$ & $36.49^{\mathrm{a}}$ & $33.09^{\mathrm{ab}}$ & $30.78^{\mathrm{b}}$ & 1.58 \\
\hline Neutrophils (\%) & $39.67^{\mathrm{a}}$ & $42.33^{\mathrm{a}}$ & $36.00^{\mathrm{b}}$ & 1.04 \\
\hline Lymphocytes (\%) & 54.67 & 56.73 & 52.67 & 1.26 \\
\hline Monocytes (\%) & 7.00 & 6.00 & 5.33 & 0.69 \\
\hline Eosinophils (\%) & 5.00 & 4.00 & 3.33 & 0.69 \\
\hline Basophiles (\%) & 0.00 & 0.00 & 0.00 & 0.00 \\
\hline
\end{tabular}

Values for $\mathrm{RBC}, \mathrm{WBC}$ and $\mathrm{Hb}$ did not vary between the treatments and were all within the normal ranges reported by Mirtuka and Rawnsley (1997). The MCV value for the GNC was below the normal range of 90 to $140 \mathrm{fl}$ reported by Mirtuka and Rawnsley (1997). The value of MCHC recorded for the LSM diet was also below the normal range of 33 to $47 \%$ reported by Mirtuka and Rawnsley (1997). Lower values of agranulocytes were generally recorded in birds fed LSM even though the differences were significant only in the case of neutrophils.

Conclusions: It can be concluded that the experimental diets used in this study contained adequate levels of protein to support growth of broilers at the starter phase. Haematological parameters were not significantly affected by treatments. LSM can therefore replace either GNC or FFS as the major source of protein in broiler starter diets without affecting the health status and performance of the birds.

\section{REFERENCES}

Adamu, A. I. (1992). Influence of weather on human health. A bioclimatic study of some communicable diseases in Sokoto. MSc. Thesis, Department of Geography, University of Ibadan.
Akpodiete, O. J and A. D. Ologhobo (1998). The nutritive value of maggot meal in broiler chicks. II - Nutrient retention, haematology and serum chemistry. In: The Nigerian Livestock Industry in the $21^{\text {st }}$ Century. Proceedings of the $3^{\text {rd }}$ Annual Conference of the Animal Science Association of Nigeria (A. D. Ologhobo and E. A. Iyayi, eds.) held at Lagos Airport Hotel, Ikeja, Lagos. September $22^{\text {nd }}-24^{\text {th }}, P$ $41-42$.

Anike, A. O. and G. C. Okeke (2003). The substitution of pigeon pea (Cajanus cajan) seed meal for soya bean in broiler finisher rations. Proceedings of the $8^{\text {th }}$ Annual Conference of the Animal Science Association of Nigeria (ASAN), Sept. $16^{\text {th }}-$ $18^{\text {th }}$, Federal university of Technology, Minna, Nigeria. P 10-12.

AOAC (1990). Association of Official Analytical Chemists Official Methods of Analysis. $15^{\text {th }}$ edition. Washington D. C.

Choct, M. and A. Kocher (2002). Non-starch carbohydrate: digestion and its secondary effects in monogastrics. http://www.personal.au/ $\Omega$ mchoct/nutsoc\%20paper.pdf.

Coles, E. H. (1978). Veterinary Clinical Pathology. $4^{\text {th }}$ edition. W. B. Saunders Company, Harcourt Brace Johanovich, Inc. 
Eggum, B. O. (1976). Indirect measures of protein adequacy. In: Protein Metabolism and Nutrition. (Coles, D. J. A., Rooman, K. N., Buttery, P. J., Lewis, D., Neals, R. J. and H. Swan, eds.). Butterworths, Boston, London. P 249-257.

Fullard, H. (1973). Phillips Modern College Atlas for Africa. $11^{\text {th }}$ ed. George Phillips and Sons Ltd., London. Pp. 71.

Hendricksen, R. E. and D. J. Minson (1985). Lablab purpureus- A Review. Commonwealth Agricultural Bureaux. Vol. 55 no. 8. Division of Tropical Crops and Pastures, CSIRO, Cunningham Laboratory, St. Lucia, Brisbane, Queensland 4067, Australia. P 215-228.

Jain, N. C. (1986). Schalms Veterinary Haematology. $4^{\text {th }}$ ed. Lea and Febiger, Philadelphia, U. S. A.

Jain, N. C. (1993). Essentials of Veterinary Haematology, $4^{\text {th }}$ ed. Lea and Febiger, Philadelphia, U. S. A.

Kwari, I. D., Igwebuike, J. U., Bello, N., Rabo, S. T. and M. Birma (2004). Replacement of groundnut cake with sorel (Hibiscus sabdariffa) seed meal in broiler finisher diets. Proceedings of the $9^{\text {th }}$ Annual Conference of the Animal Science Association of Nigeria (ASAN). Sept. $13^{\text {th }}-16^{\text {th }}$, Ebonyi State University, Abakaliki, Nigeria.

Lambourne, L. J. and I. M. Wood (1985). Nutritional quality of grain of Australian cultivars of lablab bean (Lablab purpureus). Australian Journal of Experimental Agriculture and Animal Husbandry. 55 (8): 215-228.

Liener, I. E. (1972). Heat-labile anti-nutritional factors. In: Advances in Legume Science (Summerfield, R. J. and Bunting, A. H. eds.), Royal Botanic Gardens, London, U. K. 157177.

McDonald, P., Edwards, R. A. and J. F. D. Greenhalgh (1994). Animal Nutrition. $4^{\text {th }}$ ed. Longman. U. S. A.

Mirtuka, B. M. and H. M. Rawnsley (1997). Clinical, Biochemical and Haematological Reference Value in Normal Experimental Animals. Mason Publishing Company, New York. P 35-50.

Nagabushanam, A., Srinivasan, K. S. and M. Srinivasan (1962). Amino acid composition of tender and mature field bean (Dolichos lablab). Indian Journal of Medical Research, 50: 916-919.

NRC (1977). National Research Council Nutrient Requirements of Poultry. $7^{\text {th }}$ Rev. Ed. Washington D. C.

Ogundipe, S. O., Abeke, F. O., Sekoni, A. A., Dafwang, I. I. and I. A. Adeyinka (2003). Effects of cooking duration on the utilization of Lablab purpureus beans by pullet chicks. Proceedings of the $28^{\text {th }}$ Annual Conference of the Nigerian Society of Animal Production (NSAP), $16^{\text {th }}-20^{\text {th }}$ March, I. A. R. and T., Obafemi Awolowo University, Ibadan, Nigeria.

Oldale, P. M. D. and F. Hoffman (1996). Enzymes-a tool for unlocking nutrients in animal feed. Roche Nigeria Seminar, Lagos Sheraton Hotel, Nigeria.

Olomu, J. M. (1995). Monogastric Animal Nutrition. Principles and Practice. Joachem Publishers.

Oluyemi, J. A. and F. A. Roberts (2000). Poultry Production in Warm Wet Climates. $2^{\text {nd }}$ edition. Spectrum Books Ltd. Ibadan, Nigeria.

Rueben, K. U. (1981). Geographical Regions of Nigeria. Heinman, London

Sarwatt, S. V., Ketunle, A. M. and A. J. H. Lugendo (1991). Effects of substituting Dolichos bean meal with soya bean on the performance of broiler chickens. Livestock Research for Rural Development, 3: (1).

Simarak, S., Chinrasri, O. and W. Aengwanich (2004). Haematological, electrolyte and serum biochemical values of the Thai indigenous chickens (Gallus domesticus) in northern Thailand. Songkalanakarin Journal of Science and Technology, 26 (3): 425-430.

Singh, U. (1988). Plant Foods for Human Nutrition. 43: 171-179.

SPSS (1999). Statistical Package for Social Sciences. Ver. 10.0, SPSS Inc., U S A.

Suchy, I. K. (2000). Haematological studies in adolescent breeding cocks. ACT VET BRNO, 69: 189-194.

Ubosi, C. O. and Z. A. Gworgwor (1998). Effects of age at debeaking on the performance of broiler chickens in a semiarid environment. In: The Nigerian Livestock Industry in the $21^{\text {st }}$ Century (A. D. Ologhobo 
and E. A. Iyayi eds.). Proceedings of the $3^{\text {rd }}$ Annual Conference of the Animal Science Association of Nigeria, Lagos Airport Hotel Ikeja, Lagos. Sept. $22^{\text {nd }}-24^{\text {th }}$, P 101-103.
Wood, I. M. (1983). Lablab bean (Lablab purpureus) for grain and forage production in the Ord River Irrigation Area. Australian Journal of Experimental Agricultural and Animal Husbandry, 23: 162-171. 